\title{
Pembelajaran Lompat Jauh Berbasis Kontekstual Pada Siswa Kelas V Sekolah Dasar
}

\section{Contextual-Based Long Jump Learning in $5^{\text {th }}$ Grade Elementary School Students}

\author{
Ratno Susanto ${ }^{1}$, Achmad Affandi ${ }^{2}$ \\ 1,2 Fakultas Pendidikan IImu Eksakta dan Keolahragaan, IKIP Budi Utomo Malang, Indonesia \\ email: Ratnoexecellent@gmail.com ${ }^{1}$ \\ doi: https://doi.org/10.20884/1.paju.2020.2.1.3287
}

\begin{abstract}
Abstrak
Pembelajaran Lompat menjadi salah satu materi yang diajarkan pada siswa Sekolah Dasar. Penelitian ini bertujuan: (1) mendeskripsikan perencanaan pembelajaran lompat berbasis kontekstual, (2) mendeskripsikan pelaksanaan pembelajaran lompat jauh berbasis kontekstual, (3) mendeskripsikan evaluasi pembelajaran tematik berbasis kontekstual. Metode Penelitian menggunakan deskriptif kualitatif. Sampel penelitian ini yaitu siswa kelas 5 SDN Bandungrejosari 1 berjumlah 28 orang dengan menggunakan Total Sampling. Sumber data diperoleh dari guru, siswa dan perangkat pembelajaran yang digunakan guru. Teknik pengumpulan data dilakukan dengan observasi, dokumentasi dan wawancara. Teknik analisis data yang digunakan yaitu reduksi data, display data dan penarikan kesimpulan/verifikasi. Hasil penelitian menunjukkan bahwa perencanaan pembelajaran lompat jauh berbasis kontekstual di SDN Bandungrejosari 1 sudah berjalan sebagai mana mestinya. Pelaksanaan pembelajaran lompat jauh berbasis kontekstual di SDN Bandungrejosari 1 masiah perlu ditingkatkan. Praktik pendekatan kontektual pada pembelajaraan lompat jauh masih kurang maksimal. Hal ini disebabkan guru kurang memahami dengan penerapan pendekatan pembelajaran lompat berbasis kontekstual. Terakhir, pelaksanaan evaluasi pembelajaran lompat jauh yang dipergunakan sudah sesuai dengan standar penilaian yang dipergunakan, meliputi aspek sikap, pengetahuan dan keterampilan.
\end{abstract}

Kata Kunci : Lompat Jauh, Pendekatan Kontekstual, Siswa Kelas V

\begin{abstract}
Jumping learning is one of the materials taught to elementary school students. This study aims: (1) to describe contextual-based jumping learning planning, (2) to describe the implementation of contextual-based long jump learning, (3) to describe contextual-based thematic learning evaluation. The research method used is descriptive qualitative. The sample of this research is 28 students of grade 5 SDN Bandungrejosari 1 using total sampling. Sources of data obtained from teachers, students and learning tools used by the teacher. Data collection techniques are carried out by observation, documentation and interviews. The data analysis techniques used were data reduction, data display and Alamat Koresponden : Fakultas Pendidikan IImu Eksakta dan Keolahragaan, IKIP Budi Utomo Malang

Email : Ratnoexecellent@gmail.com (c) (i)


conclusion/verification. The results showed that the contextual-based long jump learning planning at SDN Bandungrejosari 1 was running as it should be. The implementation of contextual-based long jump learning at SDN Bandungrejosari 1 still needs to be improved. The practice of a contextual approach to long jump learning is still not optimal. This is because teachers do not understand the application of contextual-based jumping learning approaches. Finally, the implementation of the long jump learning evaluation used is in accordance with the assessment standards used, including aspects of attitude, knowledge and skills.

Keywords : Long Jump, Contextual Approach, Class V Students.

\section{PENDAHULUAN}

Pembelajaran pendidikan jasmani merupakan salah satu materi yang diajarkan pada jenjang Sekolah Dasar, Sekolah Menegah Pertama dan Sekolah Menengah Atas baik sekolah negeri maupun swasta. Pembelajaran pendidkan jasmani diajarkan kepada siswa dengan tujuan untuk mengembangkan potensi yang dimiliki oleh setiap siswa melalui berbagai aktivitas fisik dan olahraga. Qohhar \& Pazriansyah (2019) menjelaskan bahwa pendidkan jasmani merupakan berbagai aktifitas fisik yang diajarkan di sekolah. Pembelajaran penjas disekoah tidak hanya bertujuan untuk mengembangkan keterampilan motorik saja, akan tetapi juga bertujuan untuk mengembangkan berbagai aspek lain pada diri siswa.

Tujuan pembelajaran pendidikan jasmani yaitu untuk mengembangkan ranah pengetahuan (kognitif), sikap (afektif) dan keterampilan (psikomotor) yang bersifat menyeluruh (Budi, Hidayat, \& Febriani, 2019). Ketiga tujuan yang ingin dicapai melalui pembelajaran pendidikan jasmani di setiap jenjang sekolah dilakukan dengan berbagai metode yang berbeda yang disesuikan dengan karakteristik siswa. Pembelajaran pendidikan jasmani di tingkat Sekolah Dasar, dilaksanakn dengan berbagai pola gerak dasar olahraga yang menyenangkan.

Pola gerak dasar berbasis multilateral sangat penting diberikan kepada siswa sekolah dasar sebagai pondasi pada perkembangan keterampilan gerak selanjutnya (Budi, Kusuma, Syafei, \& Stephani, 2019; Sayfei, Budi, Himawan Kusuma, \& Listiandi, 2020; Sina \& Pelariyanto, 2020) Pentingnya keterampilan gerak olahraga bagi siswa sekolah dasar membuat materi pembelajaran penjas memilki karakteristik keterampilan yang beragam. Di 
Ratno Susanto \& Achmad Affandi | Pembelajaran Lompat Jauh Berbasis Kontekstual Pada Siswa Kelas V Sekolah Dasar

sekolah dasar, materi pembelajaran yang diajarkan kepada siswa terdiri dari olahraga permainan, kebugaran, senam dan atletik.

Pembelajaran atletik merupakan salah satu materi wajib yang harus diikuti oleh semua siswa. Yani \& Hasri (2020) menjelaskan bahwa materi ateltik kids menjadi materi wajib bagi seluh siswa sekolah dasar. Berbagai materi yang diajarkan terdiri dari keterampilan dasar lari, lempar dan lompat (Sidik, 2010; Sina \& Pelariyanto, 2020). Materi lompat pada pembelajaran atletik di sekolah dasar perlu diajarkan kepada siswa dalam bentuk lompat katak dan lompat jauh.

Materi lompat jauh diajarkan kembali pada mata pelajaran pendidkan jasmani di Sekolah Dasar pada tahun 2013 hingga sekarang dengan perubahan-perubahan yang signifikan (Diknas, 2012; Adi, 2015). Pembelaajran lompat jauh memiliki berbagai kriteria gerakan, seperlti berlari, koordinasi berbagai anggota tubuh dan gerakan melompat. Materi lompat menjadi salah satu yang dapat meningkatkan keterampilan gerak atletik siswa sekolah dasar (Rumini, 2014). Salah satu pendekatan pembelajaran yang dapat digunakan dalam pembelajaran lompat jauh pada siswa sekolah dasar yaitu contextual teaching and learning.

Pembelajaran berbasis kontekstual dilaksanakan oleh guru dengan menghubungakan antara pengetahuan yang dimiliki oleh siswa dengan penerapan dalam kehidupan sehari-hari (Siregar \& Nara, 2014). Pembelajaran kontekstual dikatakan penting karena proses pembelajarannya menekankan kepada keterlibatan aktif siswa dalam belajar atau student centered and learning context. Pelaksanaan pembelajaran dengan metode kontekstual dilaksanakan secara alami karena siswa tidak hanya belajar secara konsep saja, akan tetapi juga dapat mempraktekan dan memecahkan permasalahan secara langsung, melalui kondisi lingkungan tempat tingal anak (Hasnawati, 2016).

Berdasarkan hasil observasi yang dilakukan di SDN Bandungrejosari 1 kota Malang, menunjukkan bahwa pembelajaran lompat jauh dalam mata pelajaran pendidikan jasmani yang sedang terjadi masih memiliki berbagai permasalahan, diantarnya perencanaan pembelajaran yang dilakukan guru, proses pembelajaran yang dilaksanakan serta proses evaluasi pembelajaran. Permasalahan yang terjadi pada pembelajaran materi lompat jauh perlu dikaji lebih jauh mengenai penyebabnya dan sekaligus mencari solusi mealui pendekatan pembelajaran kontekstual. 
Tujuan dari penelitian ini yaitu untuk 1) mendeskripsikan perencanaan pembelajaran lompat berbasis kontekstual, (2) mendeskripsikan pelaksanaan pembelajaran lompat jauh berbasis kontekstual, (3) mendeskripsikan evaluasi pembelajaran tematik berbasis kontekstual.

\section{METODE}

Penelitian ini merupakan salah satu jenis penelitian deskriptif kualitatif. Sugiyono (2016) menyatakan bahwa penelitian deskriptif merupakan jenis penelitian yang bertujuan untuk menguraikan suatu keadaan tanpa adanya perlakuan terhadap obyek yang diteliti. Pelaksanaan penelitian dan kajiannya didasarkan pada proses pencarian data secara lengkap. Subjek penelitiannya adalah siswa kelas V SDN Bandungrejosari 1 Kota Malang yang berjumlah 28 .

Data yang diperoleh. Prosedur pengumpulan data dilakukan dengan cara observasi, wawancara, dan dokumentasi tentang pembelajaran tematik berbasis kontekstual di SDN Bandungrejosari 1 Kota Malang. Analisis data pada penelitian ini menggunakan analisis Miles and Huberman (Moleong, 2015) mencakup 3 langkah yaitu:

1) Data Reduction (Reduksi Data). Memilih berbagai data yang penting dan mendukung penelitian seperti: dokumen RPP, dokumen wawancara dan angket peneltian .

2) Data Display (penyajian data). Data hasil peneitian yang diperoleh berupa hasil angket dan wawancara, kemudian hasil tersebut diolah untuk menjadi temuan penelitian

3) Conclusion Drawing/Verification. Kesimpulan yang diperoleh berupa data kualitatif berdasarkan hasil penelitian. Kesimpulan bersifat sementara karena apabila ada temuan lebih lanjut dan memberikan gambaran lain mengenai peneltiian maka dapat digunakan.

4) Pengecekan keabsahan data dilakukan dengan trianggulasi. Dilakukan dengan cara pengecekan kembali kepada sumber yang memiliki keterkaitan langsung mengenai data penelitian. 
Ratno Susanto \& Achmad Affandi | Pembelajaran Lompat Jauh Berbasis Kontekstual Pada Siswa Kelas V Sekolah Dasar

HASIL

\section{Rencana Pelaksanaan Pembelajaran (RPP)}

Rencana Pelaksanan Pembelajaran (RPP) merupakan acuan bagi guru dalam melaksanakan proses pembelajaran. Materi yang diberikan kepada siswa dilapangan harus sesuai dengan apa yang telah disusun dalam RPP. Didalam RPP terdiri atas KD, tujuan pembelajaran, materi pembelajaran, metode pembelajaran, langkah-langkah pembelajaran, sumber belajar, dan penilaian. Tujuan utama dari penyusunan RPP yaitu untuk dapat mencapat tujuan pembelajaran yaitu mengembangkan kompetensi yang dimiliki oleh siswa.

Hasil penelitian menunjukan bahwa guru PJOK di SDN Bandungrejosari 1 Kota Malang telah menyusun RPP dengan baik sebagai acuan dalam proses pembelajaran, RPP disusun dalam satu perangka pembelajaran sehinga guru memiliki pedoman yang jelas dalam melakukan proses pembelaajran, materi yang diberikan kepada siswa yaitu lompat jauh juga telah memiliki RPP sebagai dasar pemberian materi dengan pendekatan pembelajaran kontekstual.

\section{Bahan Ajar dan Proses Pembelajaran}

Bahan ajar merupakan komponen penting yang harus dimiliki oleh guru, dalam hal ini guru mata pelajaran PJOK di sekolah dasar. Bahan ajar yang digunakan guru mengacu pada Kompetensi Dasar (KD) dan tujuan pembelajaran yang telah ditetapkan oleh guru pada silabus dan RPP. Bahan ajar juga dapat berupa buku, internet, poster, peralatan olahraga, modifikasi peralatan dan sebaginya. Dengan bahan ajar yang memadai maka proses pembelajaran dapat berjalan dengan baik.

Bahan ajar ini memuat materi-materi yang mencerminkan pendekatan kontekstual. Materi-materi yang dimuat pada bahan ajar tidak lepas dari kehidupan siswa. materi-materi pembelajaran disesuaikan dengan lingkungan tempat tinggal siswa, sehinga siswa dapat melakukan proses belajar lompat jauh yang disesuaikan dengan kondisi wilayah tempat tnggal siswa.

Bahan ajar yang digunakan bertujuan untuk menunjang proses pembelajaran lompat jauh, akan tetapi hasil penelitian menunjukan bahwa pada proses pembelajaran lompat jauh melalui pendekatan kontekstual, guru belum dapat melaksanakan proses 
pembelajaran dengan baik. hal ini dikarenakan guru belum menguasai secara baik keterampilan mengajar melalui pendekatan kontekstual.

\section{Alat Penilaian/ Evaluasi}

Pelaksanaan evaluasi pembelajaran dilakukan guru untuk mengtahui perkembangan yang dialami oleh siswa selama proses pembelajaran lompat jauh. Penyusunan indikator penilaian dilakukan berdasarkan Silabus dan RPP yang dibut oleh guru, sehingga hasil evaluasi dapat diketahui secara akurat. Hasil penelitina ini menunjukan bahwa evaluasi yang dilaukan guru mencakup hasil belajar dalam aspek pengetahuan dan keterampilan. Evaluasi pada ranah pengetahuan dilakukan dengan peberian tugas, pertanyaan selama proses pembelajaran dan berbagai ujian tertulis, sedangkan untuk mengukur kemajuan belajra dalam ranah keterampilan, guru melakukan tes keterampilan gerak lompat jauh kepada siswa. Hasil dari evaluasi tersebut dijadikan acuan dalam proses perbaikan pembelajaran yang dilakukan oleh guru.

\section{PEMBAHASAN}

\section{Tahap Perencanaan Pembelajaran}

Perencanan Pembelaajran atau RPP merupakan komponen utama dalam sebuah pembelajaran, khususnya pembelajaran PJOK di jenjang sekolah dasar. Perencanaan pembelajaran wajib dimiliki oleh semua guru mata pelajaran (Arisandi, 2014). Hasil penelitian menunjukan bahwa perencanaan pembelajaran pada mata pelajaran PJOK di SDN Bandungrejosari 1 Kota Malang telah disusun dengan baik. Guru mata pelajaran PJOK menyusun perangkat pembelajaran sebagai salah satu kewajiban baik secara administrasi maupun sebagai panduan dalam mengajar.

Perangkat pembelajaran yang disusun dengan baik dapat membantu guru dalam pelasanaan pembelajran PJOK di ekolah dasar. Perencanaan pembelajran perlu disusun oleh guru karena pada tingkat sekolah dasar, siswa belajar melalui berbagai permainan yang menyenangkan (Hanief, Subekti, \& Mashuri, 2018). Perencanaan pembelajaran yang dirancang dengan baik oleh guru dapat membantu keterlibatan aktif siswa dalam pembelajaran PJOK di SDN Bandungrejosari 1 Kota Malang. 
Ratno Susanto \& Achmad Affandi | Pembelajaran Lompat Jauh Berbasis Kontekstual Pada Siswa Kelas V Sekolah Dasar

\section{Tahap Pelaksanaan Pembelajaran}

Pada tahap pelaksanaan pembelajaran, guru tidak sepenuhnya melaksanakan pembelajaran mengacu pada RPP yang telah disusun sebelumnya. padahal, di RPP telah jelas setiap langkah yang harus dilakukan agar tidak lepas dari perencanaan awal. Guru masih kesulitan dalam menentukan praktik dalam proses pembelajaran. Hasil penelitian terdahulu juga menunjukan pda proses mengajar, guru sekolah dasar masih mengalam berbagai kendala (Pratomo, 2009; Laila et al., 2016). Guru belum mampu melaksanakan semua langkah-langkah yang dibuat di RPP. Hal ini disebabkan, guru menganggap pendekatan kontekstual merupakan hal baru bagi guru, sehingga guru menjadi canggung dalam melaksanakannya di dalam kelas.

Meskipun guru masih kesulitan dalam melaksanakan langkah-langkah pembelajaran kontekstual, guru masih terbantu dengan adanya bahan ajar yang mengacu pada RPP berbasis kontekstual. Pada bahan ajar tersebut memuat konten-konten materi berbasis kontekstual. Pada bahan ajar berbentuk guru memuat tujuan pembelajaran, materi, gambar, dan evaluasi pembelajaran. Tujuan pembelajaran tersebut mengacu pada RPP yang telah disusun. Materi yang dimuat pada bahan ajar tersebut mendeskripsikan tentang kondisi atau kehidupan di lingkungan tempat tinggal siswa khususnya lingkungan kota Malang. Materi yang disusun disesuaikan dengan kondisi sebenarnya memungkinkan siswa untuk lebih mudah dalam menyerap pelajaran yang diajarkan oleh guru.

Dengan demikian, bahan ajar yang dibuat berbasis pendekatan kontekstual sangat membantu guru dalam melaksanakan pembelajaran di ruang dan luar kelas. Pada pelaksanaan pembelajaran, guru menjadi fasilitator yang memfasilitasi siswa dalam menemukan pengetahuannya sendiri. Kekurangan guru dalam memahami pembelajaran lompat jauh berbasis kontekstual dapat tertutupi dengan adanya bahan ajar berbasis kontekstual.

\section{Tahap evaluasi}

Pada tahap evaluasi merupakan tahap terpenting bagi guru dan siswa. Jenis alat ukur yang digunakan dalam proses pembelajaran PJOK di kelas menggunakan alat ukur tes berbentuk pilihan ganda untuk mengetahui tingkat pemahaman siswa. Penilaian keterampilan dilakukan untuk megetahui tingkat penguasaana gerak lompat yang dimiliki 
oleh siswa. Penilaian keterampilan menjadi komponen utama dalam pengukuran pembelajran praktek di sekolah (Setiawan et al., 2020).

Sebelum instrument disusun, guru menyusun kisi-kisi soal. Tujuan penyusunan kisi-kisi soal yaitu untuk mempermudah guru dalam membuat soal dan mempermudah dalam membuat pilihan atau opsi pada pilihan jawaban. Pembuatan kisi-kisi soal dapat mempermudah guru menyusun soal sehingga tidak keluar dari indikator pencapaian yang diharapkan oleh guru. Penggunaan alat ukur tes pilihan ganda dianggap lebih mudah untuk menilai kemampuan siswa, karena dapat mengukur kemampuan siswa dalam memahami pelajaran.

Penggunaan tes pilihan ganda serta praktik dilakukan diakhir proses pelaksanaan pembelajaran di kelas. Hal ini bertujuan untuk mengukur kemampuan akhir siswa. Setelah kemampuan siswa telah terukur, maka guru memberikan penilaian pada hasil belajar siswa. Dengan demikian, hasil belajar yang telah terukur dapat dijadikan patokan keberhasilan proses pembelajaran yang telah dilaksanakan di dalam kelas.

\section{SIMPULAN}

Pembelajaran lompat jauh berbasis kontekstual masih perlu ditingkatkan sehingga proses pembelajaran dapat dilaksanakan dengan lebih edektif. Proses evaluasi pembelajaran telah berjalan dengan baik karena mencakup ranah pengetahuan, sikap dan keterampilan. Berdasarkan hasil telaah diharapkan guru lebih bisa memahami pembelajaran kontekstual sehingga pelaksanaan pembelajaran lompat jauh di tingkat sekolah dasar dapat lebih optimal. Saran dari penelitian ini yaitu Guru pendidikan jasmani disarankan untuk lebih inovatif dalam menerapkan metode dan model pembelajaran, selain itu juga dapat mengunakan modifikasi pembelajaran yang sesuai. Penelitian selanjutnya dapat menggunakan sampel yang lebih banyak dan dari jenjang pendidikan yang lebih tinggi 
Ratno Susanto \& Achmad Affandi | Pembelajaran Lompat Jauh Berbasis Kontekstual Pada Siswa Kelas V

\section{REFERENSI}

Arisandi, A. (2014). Pelaksanaan Pembelajaran Pendidikan Jasmani Olahraga Dan Kesehatan Bagi Anak Cerebral Palsy Kelas V.d Di SLB YPPLB Padang. In EJUPEKhu(Jurnal IImiah Pendidikan Khusus).

Budi, D. R., Hidayat, R., \& Febriani, A. R. (2019). The Application of Tactical Approaches in Learning Handballs. JUARA: Jurnal Olahraga. https://doi.org/10.33222/juara.v4i2.534

Budi, D. R., Kusuma, M. N. H., Syafei, M., \& Stephani, M. R. (2019). The Analysis of Fundamental Movement Skill in Primary School Student in Mountain Range. https://doi.org/10.2991/icsshpe-18.2019.56

Hanief, Y. N., Subekti, T. B. A., \& Mashuri, H. (2018). Meningkatkan Hasil Belajar Passing Bawah Bolavoli melalui Permainan 3 on 3 pada Siswa Sekolah Dasar. Jurnal Pendidikan Jasmani Dan Olahraga. https://doi.org/10.17509/jpjo.v3i2.12414

Laila, Q. N., Tinggi, S., Tarbiyah, I., Al, N., \& Mojokerto, H. (2016). Pembelajaran Tematik Terpadu Pada Jenjang SD/MI. MODELING: Jurnal Program Studi PGMI.

Qohhar, W., \& Pazriansyah, D. (2019). Pengaruh Model Pembelajaran Kooperatif Tipe Teaching Games For Understanding (TGFU) Terhadap Peningkatan Hasil Belajar Teknik Dasar Sepakbola. Physical Activity Journal, 1(1), 27-35. https://doi.org/doi:10.32424/1.paju.2019.1.1.1998

Rumini. (2014). Pembelajaran Permainan Kids Athletics Sebagai Wujud Pengembangan Gerak Dasar Atletik Pada Anak-Anak. Journal of Physical Education Health and Sport, 1(2). https://doi.org/10.15294/jpehs.v1i2.3208

Sayfei, M., Budi, D. R., Himawan Kusuma, M. N., \& Listiandi, A. D. (2020). Identifikasi Keberbakatan Menggunakan Metode Australian Sport Search Terhadap Kesesuaian Cabang Olahraga Pada Anak Sekolah Dasar. Physical Activity Journal. https://doi.org/10.20884/1.paju.2020.1.2.2285

Setiawan, A., Yudiana, Y., Ugelta, S., Oktriani, S., Budi, D. R., \& Listiandi, A. D. (2020). Hasil Belajar Pendidikan Jasmani dan Olahraga Siswa Sekolah Dasar: Pengaruh Keterampilan Motorik (Tinggi) dan Model Pembelajaran (Kooperatif). TEGAR: Journal of Teaching Physical Education in Elementary School. https://doi.org/10.17509/tegar.v3i2.24513

Sidik, D. Z. (2010). Prinsip Prinsip Latihan Dalam Olahraga Prestasi (Rosda, ed.). Bandung.

Sina, I., \& Pelariyanto, E. (2020). Pengaruh Latihan Skipping Terhadap Hasil Loncat Katak Pada Siswa Sekolah Dasar. Physical Activity Journal. https://doi.org/10.20884/1.paju.2020.1.2.2471 
Sugiyono, P. D. (2016). metode penelitian kuantitatif, kualitatif,dan R\&D. In Alfabeta, CV. Bandung: Alfabeta.

Yani, A., \& Hasri, R. (2020). Hubungan Panjang Tungkai Dengan Kecepatan Lari 60 Meter Siswa Sekolah Dasar. Physical Activity Journal. https://doi.org/10.20884/1.paju.2020.1.2.2423 